niques et des installations d'élevage. En effet, on observe une accélération du rythme de reproduction (mise à la reproduction et sevrage plus précoces, réduction des temps improductifs) et la diminution du taux de mortalité des porcelets.

Les causes "gériétiques " de ce progrès ne peuvent être recherchées que dans l'extension de l'usage des croisements dont l'effet sur la précocité sexuelle ( 8 p. I oo), l'intervalle sevrage -fécondation ( $16 \mathrm{p}$. I $\mathrm{roo}$ ) et le taux de survie des porcelets ( $8 \mathrm{p}$. roo) est loin d'être négligeable.

Or, l'approche d'une "limite biologique " pour le rythme de reproduction et l'évolution des structures d'élevage ramènent au premier rang des priorités l'amélioration de la taille de la portée à la naissance, critère pour lequel on n'observe aucun progrès génétique, voire une légère diminution en race Lavge White. L'abandon de la sélection sur ce caractère pardonnable au cours de la période d'engouement pour les croisements que nous venons de vivre est une position qui mérite d'être reconsidérée sous peine de compromettre l'avenir de nos races. Le classement des truies sur indice de prolificité intra-élevage permet à l'éleveur d'espérer un progrès génétique de l'ordre de 0,5 porcelet par portée tous les dix ans sans compromettre les possibilités de sélection sur engraissement et carcasse. Il permet également d'envisager la création d'une lignée spécialisée sur la prolificité dont les verrats sont utilisables en insémination artificielle, aussi bien en race pure qu'en croisement.

\title{
EFTEKTIVITÄT VERSCHIEDENER PRÜFUNGSMETHODEN FUR DIE ZUCHTWAHL VON EBERN UND SAUEN IN REINZUCHTPOPULATIONEN
}

\author{
D. FEWSON, E. NIEBEL \\ Abteilung Tievzuchtung dev Universität Hohenheim, Postfach Io6 \\ 7000 Stuttgart, 70 Bundesvep, Deutschland
}

Es werden die Ergebnisse von Planungsrechnungen zur Effektivität alternativer Prüfungsmethoden fur die Zuchtwahl von Ebern und Sauen diskutiert.

I. Die Eigenleistungsprüfung der Eber im Feld in Kombination mit einer Voll-und Halbgeschwisterprüfung aus Station ist allen anderen Prüfungsmethoden überlegen, $a$ ) wenn die Fleischbeschaffenheit eine hohe wirtschaftliche Bedeutung hat, $b$ ) alle zuchttauglichen männlichen Tiere aus Prüfungswurfen im Feld aufgezogen und getestet, $c$ ) nur die Fber mit dem höchsten Zuchtwert zur Nachzucht von Jungebern eingezetzt und $d$ ) die Informationen aus der Stationsprüfutig auch für die Sauenselektion herangezogen werden.

2. Durch die Sauenselektion kann der Zuchtfortschritt wesentlich verbessert werden. Neben der Eigenleistung im Feld sollten die Geschwisterinformationen aus der Station für die Zuchtwahl der Sauen ausgenutzt werden.

ESTIMATION OF REALISED GENETIC CHANGE FOR TRAITS IN THE SWEDISH PIG POPULATION

\section{A ZARNECKI}

Dep. of Animal Bveeding and Geneics

Swedish University of Agricultural Sciences, S-75590 Uppsala, Sweden

The SmiTh's technique for estimating genetic changes was applied on date from the pig progeny testing stations in Sweden. Data from a 5 year period was used: from October 1 , I 968 to September 30,1973 , during which no major changes in management were made. After exclusion of boars with only one progeny group, 5376 groups remained. The calculations were carried out on actual records and deviations within stations from $a$ ) quarterly averages, $b$ ) moving averages with the group at the mid-point, and c) moving averages with the group at the end. Both kinds of moving averages contained 30 groups. Favourable phenotypic changes have taken place in all important production traits. The biggest gain, expressed as a percentage of the mean total was achieved in slight of lean and inside fat (over 4 p. Ioo), and over 2 p. Ioo gain in four backfat thickness measurements.

The estimates of the annual genetic changes were very large and in most cases larger than the phenotypic trends. Different estimates for the same traits seem to be quite uniform. It seems very likely that the genetic changes were overestimated due to a certain selection taking 